\section{Funding breakthroughs}

\section{By Tracey Baas, Senior Editor}

The $\$ 33$ million in prize money from the Breakthrough Prize in Life Sciences Foundation went to 11 deserving scientists. But it is worth debating whether, in an age of austerity, there are more efficient ways for the billionaire backers to put their money to work.

One line of thought holds that giving money to young researchers might be a better use of new funds than giving prize money to established researchers who already are well funded.

But at least two of the winners, as well as representatives from other philanthropies, think that essentially any form of large, long-term investigator award will give scientists more freedom than traditional grant-based research funding.

The Breakthrough Prize in Life Sciences Foundation was created by Art Levinson, Sergey Brin, Anne Wojcicki, Mark Zuckerberg, Priscilla Chan and Yuri Milner (see Table 1, "Founders and awardees"). Its stated goals are "advancing breakthrough research, celebrating scientists and generating excitement about the pursuit of science as a career," according to the foundation's website.

To achieve this, the foundation awarded $\$ 3$ million to each of 11 researchers. The awardees together cover a broad range of research activities, but the primary focus underlying much of the work is cancer. Recipients were selected by the foundation's board, and next year's recipients-of which there will be five-will be selected by a committee made up of this year's winners.

The cash infusion clearly checks boxes two and three of the foundation's goals, but whether breakthrough research will follow is anyone's guess.

Three executives at research-supporting philanthropies say long-term awards to investigators of varying ages, rather than via prizes, are a good way to fund big ideas and drive innovation.

"We do not fund science through prizes. We find that our competitive investigator award schemes serve our goals and provide the flexibility and security that researchers need to tackle major scientific challenges," said Kevin Moses, director of science funding at the Wellcome Trust.

Wellcome provides annual funding of up to $£ 425,000(\$ 640,000)$ to both new and senior investigators for up to 7 years.

In 2009, the organization announced it would stop offering project grants and instead offer the investigator awards. It has given 20 new investigator awards and 83 senior investigator awards at 27 different U.K. institutions and 1 overseas institution.

"To select candidates, we make an assessment of their potential and probability of doing significant science in the next-funded period, based on both their track record and their proposal," said Moses. "We depend on help from outside scientists and clinicians for advice."

Jack Dixon, VP and CSO of the Howard Hughes Medical Institute, noted that young blood was absent from the first round of the $\$ 3$ million prizes.

"The Breakthrough Prize in Life Sciences Foundation has selected an impressive group of people-terrific scientists-to give their awards to, but looking at the list, none of these individuals are beginners," he said. "Shinya Yamanaka has already won a Nobel Prize, and three of their awardees-Cornelia Bargmann, Charles Sawyers and Bert Vogelsteinare Howard Hughes Medical Institute investigators."

HHMI supports about 330 independent researchers as investigators at institutions throughout the U.S. By appointing scientists as HHMI investigators, rather than awarding them traditional grants for specific research projects, the researchers receive flexible funding for five years.

About $80 \%$ of the HHMI investigators are reappointed following a review process. HHMI also provides 6 years of funding to an additional 45 early career scientists-individuals who are 2-5 years into their tenure-track career.

The Paul G. Allen Family Foundation has been giving a growing portion of its awards to younger investigators. Of the 5 new Allen Distinguished Investigators awards announced last month, each ranging from \$1.4 million to \$1.6 million, none was given to a tenured professor.

"We are looking for the most innovative project proposals, and we're not biased against a researcher's $\mathrm{CV}$, publication record or point in their career," said VP Sue Coliton. "We have already seen progress come out of our first cohort-including a spinoff company called Inscopix Inc. that came from a brain-imaging technology development from one of our investigators."

The NIH has also been setting aside money to fund outside-the-box thinkers. It offers the NIH Director's Pioneer Award, the NIH Director's New Innovator Award, the NIH Director's Transformative Research Award and the NIH Director's Early Independence Award.

"The Pioneer Awards have been around for about 10 years, so we can see the award provides a pretty clear opportunity for groundbreaking research," said NIH director Francis Collins. "We've had some exciting work come out of these awards but also some failures, which just goes to show that you can't have interesting success stories without taking on some risk."

Collins added, "One of the newly awarded Breakthrough Prize scientists-Titia de Lange-received one of our Pioneer Awards in 2005. It is encouraging to see that type of endorsement for a scientist and projects that are traditionally considered 'too risky,"' he said.

The Pioneer Award provides scientists with up to $\$ 750,000$ in research and indirect costs per year for 5 years.

"I think it's great that The Breakthrough Prizes in Life Sciences Foundation is providing such a large financial incentive to attract public attention and get young people interested in science," Collins said. "I am delighted that they are able to provide that type of recognition, because we at the NIH wouldn't be able to give an unrestricted personal prize of this magnitude with tax payers' money." 


\section{Prized fighters}

Hans Clevers, a Breakthrough awardee who is professor of molecular genetics at the Hubrecht Institute and president of the Royal Netherlands Academy of Arts and Sciences, thinks a key advantage of awards versus grants is operating freedom.

Clevers has received multiple prizes and awards. To name a few, he is a past recipient of the Dutch Spinoza Award-a Dutch equivalent of the Nobel Prize - which provides $€ 2.5$ million ( $\$ 3.3$ million) for research purposes; the Louis-Jeantet Prize, which provides $€ 400,000$
(\$520,000) for research and $€ 75,000(\$ 98,000)$ for personal use; and the Heineken Prize, which provides $€ 150,000(\$ 200,000)$ for personal use.

"There is no timeline for when you need to use the money," he said. "I have felt secure in hiring people because I have money set aside to pay for salaries if fellowships don't come through. I could never do this with a traditional grant because at the end of the grant, the money has to be used or you lose it. Also, unlike grants, the money can be used for expensive equipment, such as two-photon microscopes or gene arrayers, that my

Table 1. Founders and awardees.

\begin{tabular}{ll}
\hline Founders & Title(s) \\
\hline Sergey Brin & Cofounder of Google Inc.
\end{tabular}

\begin{tabular}{|c|c|}
\hline Priscilla Chan & \\
\hline Art Levinson & $\begin{array}{l}\text { Chairman of Apple, chairman of Roche's Genentech Inc. unit and } \\
\text { member on the board of directors for Roche. Chairman of the board } \\
\text { of directors for the Breakthrough Prize in Life Sciences Foundation }\end{array}$ \\
\hline Yuri Milner & $\begin{array}{l}\text { Founder of the internet company Mail.ru Group. Member of the } \\
\text { board of directors for the Breakthrough Prize in Life Sciences } \\
\text { Foundation }\end{array}$ \\
\hline Anne Wojcicki & $\begin{array}{l}\text { Cofounder of privately held personal genetics company 23andMe } \\
\text { Inc. Member of the board of directors for the Breakthrough Prize in } \\
\text { Life Sciences Foundation }\end{array}$ \\
\hline Mark Zuckerberg & $\begin{array}{l}\text { Founder, chairman and CEO of Facebook Inc. Member of the board } \\
\text { of directors for The Breakthrough Prize in Life Sciences Foundation }\end{array}$ \\
\hline Awardee & Title(s) \\
\hline $\begin{array}{l}\text { Cornelia } \\
\text { Bargmann }\end{array}$ & $\begin{array}{l}\text { Professor and head of the Lulu and Anthony Wang Laboratory of } \\
\text { Neural Circuits and Behavior at The Rockefeller University and a } \\
\text { Howard Hughes Medical Institute (HHMI) investigator }\end{array}$ \\
\hline David Botstein & $\begin{array}{l}\text { Director of the Lewis-Sigler Institute for Integrative Genomics at } \\
\text { Princeton University and professor of genomics at Princeton }\end{array}$ \\
\hline Lewis Cantley & $\begin{array}{l}\text { Professor and director of the Cancer Center at Weill Cornell Medical } \\
\text { College and New York-Presbyterian Hospital }\end{array}$ \\
\hline
\end{tabular}

\section{Science background}

Bachelor's degree in mathematics and computer science from the University of Maryland, College Park and a master's degree in computer science from Stanford University, where he is currently on leave from the $\mathrm{PhD}$ program

Bachelor's degree in biology from Harvard University and a medical degree from the University of California, San Francisco

Bachelor's degree in molecular biology from the University of Washington and a $\mathrm{PhD}$ in biochemical sciences from Princeton University

Advanced degree in theoretical physics from Lomonsov Moscow State University and subsequently conducted research at the Institute of Physics at the Russian Academy of Sciences

Bachelor's degree in biology from Yale University

Studied computer science at Harvard

\section{Research focus}

Genetics of neural circuits and behavior, and synaptic guidepost molecules

Linkage mapping of Mendelian disease in humans using DNA polymorphisms

Wingless-type MMTV integration site (WNT) signaling in tissue stem cells and cancer

Mechanisms of angiogenesis that lead to therapies for cancer and eye diseases

Telomeres-illuminating how they protect chromosome ends and their role in genome instability in cancer

General principles for identifying human disease genes and enabling their application to medicine through the creation and analysis of genetic, physical and sequence maps of the human genome of Technology (MIT) and professor of systems biology at Harvard Medical School

\begin{tabular}{ll}
\hline Charles Sawyers & $\begin{array}{l}\text { Chair of human oncology and the pathogenesis program at Memorial } \\
\text { Sloan-Kettering Cancer Center and an HHMI investigator }\end{array}$ \\
\hline Bert Vogelstein & $\begin{array}{l}\text { Director of the Ludwig Institute for Cancer Research, professor } \\
\text { of oncology and pathology at The Sidney Kimmel Comprehensive } \\
\text { Cancer Center at The Johns Hopkins University School of } \\
\text { Medicine and an HHMI investigator }\end{array}$
\end{tabular}

Robert Weinberg Professor for cancer research at MIT, director of MIT's Ludwig Center for Molecular Oncology and a member of the Whitehead Institute for Biomedical Research

Shinya Yamanaka Director of the Center for iPS Cell Research and Application at Kyoto University and senior investigator at The J. David Gladstone Institutes

Characterization of human cancer genes

Induced pluripotent stem cells
Cancer genomics and tumor suppressor genes 


\section{ANALYSIS}

\section{TRANSLATIONAL NOTES}

laboratory students and postdocs are interested in trying-just to see if it might further their research."

Clevers also said that being free from the cycle of grant writing allows for more creative research. "The idea of exploration is what these types of awards foster. I have had about 30-40 manuscripts published in high-impact journals like Nature, Cell and Science," he said. "Those publications have all come out of work that I never had to write a grant

"These types of awards are very important to provide support for basic research that seems to have no immediate or obvious payoff but in the long run contributes to medical breakthroughs."

- Cornelia Bargmann, The Rockefeller University for. My breakthrough papers have come from awards-like Spinoza or Louis-Jeantet-that allowed me the freedom to explore. My work from aim-based grant proposals typically does not make the highimpact journals."

Cornelia Bargmann, a Breakthrough awardee who is professor and laboratory head at The Rockefeller University and an HHMI investigator, agreed that freedom in research is what yields scientific advances. "I have had the huge privilege of being an HHMI investigator since 1995, and I understand how having that money provides you with the freedom to explore different aspects of your work," she said. "Rockefeller has also contributed to that freedom, showing me that my work is valuable by providing me with funding and my graduate students with salaries."

Traditionally, graduate student salaries are paid from grants received by their professor or from student fellowships that also are based on grant proposals.

"These types of awards are very important to provide support for basic research that seems to have no immediate or obvious payoff but in the long run contributes to medical breakthroughs," said Bargmann. "When there is a clear lead or target to go after or treat disease, that is where big pharmas can take the lead-and they are very good at that. It is what they do. But academic scientists, exploring basic research problems-they are going to provide the information as to where or what those leads or targets may be. It is what we do best."

\section{Future funding}

Ultimately, it will be up to the Breakthrough Prize's selection committee to determine which scientists and what type of basic research problems should receive dollars.

Yuri Milner's other big-money philanthropy—the Fundamental Physics Prize Foundation-provides a good case study. In its inaugural year of 2012, the Foundation awarded 9 Fundamental Physics Prizes, each at $\$ 3$ million.

This year, the foundation's selection committee chose five laureates to receive the Physics Frontiers Prize, which recognizes transformative advances in the field, and three laureates to receive the New Horizons in Physics Prizes, which target promising junior researchers.

The New Horizon awardees will receive $\$ 100,000$. The Physics Frontiers Prize awardees will receive $\$ 300,000$ and will become nominees for the Fundamental Physics Prize.

Baas, T. SciBX 6(9); doi:10.1038/scibx.2013.207

Published online March 7, 2013

\section{COMPANIES AND INSTITUTIONS MENTIONED}

Breakthrough Prize in Life Sciences Foundation, no location provided

Fundamental Physics Prize Foundation, no location provided Howard Hughes Medical Institute, Chevy Chase, Md.

Hubrecht Institute, Utrecht, the Netherlands

Inscopix Inc., Palo Alto, Calif.

National Institutes of Health, Bethesda, Md.

The Paul G. Allen Family Foundation, Seattle, Wash.

The Rockefeller University, New York, N.Y.

Royal Netherlands Academy of Arts and Sciences, Amsterdam, the Netherlands

Wellcome Trust, London, U.K. 